\title{
THE GENUS TRIAERIS SIMON (ARANEAE, OONOPIDAE) IN CENTRAL AMERICA AND THE WEST INDIES.*
}

\author{
By Arthur M. Chickering \\ Museum of Comparative Zoology
}

Since my first contact with the Genus Triaeris Simon in 1939 in Panama I have continued to collect these interesting little spiders at every opportunity during my collecting trips to parts of Central America and the West Indies. Simon established the genus Triaeris in $\mathrm{I} 89 \mathrm{I}$ on the basis of females from St. Vincent, B. W. I. He also stated that he had the same species from Venezuela. In 1940 Miss Elizabeth Bryant described what she regarded as the female of a new species from Cuba. In 1948 she reported Simon's species from Haiti. In $195 \mathrm{I}$ I reported $T$. patellaris Bryant from Panama. As will be shown later in this paper I have now decided that $T$. patellaris Bryant is a synonym for T. stenaspis Simon. I believe that I now have this species from several localities in Central America and numerous localities in the West Indies as well as one record from Southern Florida. According to my present view, the male of T. stenaspis Simon is still unknown. After a period of uncertainty it now seems that I have a new species of this genus represented by a male from St. Croix, U. S. Virgin Islands and a female from Nevis, B. W. I. Two males from Trinidad, W. I. seem to represent another new species. I am, therefore, compelled to recognize three species of the genus Triaeris from the region under study. The female of Triaeris lepus Suman has recently been described from Hawaii.

All types, together with my entire collection of this genus, are being deposited in the Museum of Comparative Zoology, Harvard University.

Grants GB-1801 and GB-5013 from the National Science Foundation have furnished financial aid for several collecting trips in Central America, Florida and the West Indies together with my continued research in the Museum of Comparative Zoology for nearly six years. I am deeply grateful for the help and encouragement received from members of the staff of the Museum of Comparative Zoology over a period of many years. Special acknowledgements should be extended to Dr. Ernst Mayr, Director; Dr. P. J. Darlington, Jr., Alexander Agassiz Professor of Zoology; Dr. Herbert W. Levi, Associate

*Manuscript received by the editor September 10, 1968 

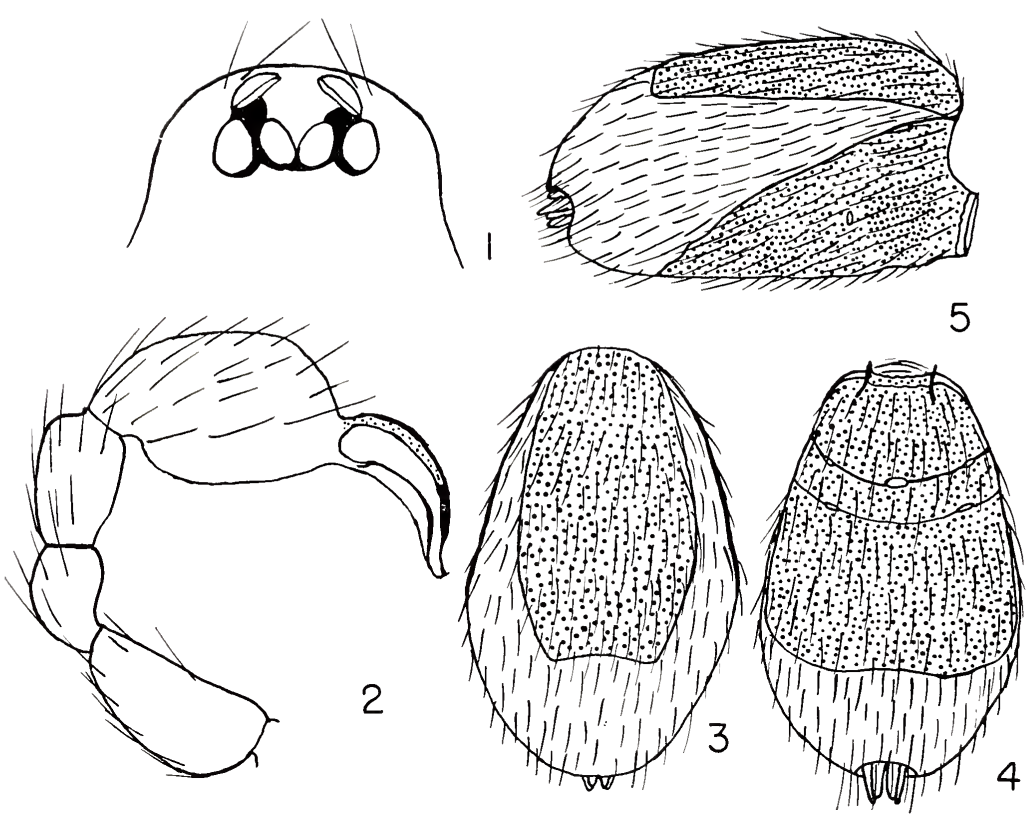

Figures 1-5. Triaeris bodanus sp. nov. Fig. 1. Eyes of male from above. Fig. 2. Left male palp; prolateral view. Figs. 3-5. Abdomen of male; dorsal, right lateral and ventral views, respectively.

Curator of Arachnology; Miss Nelda Wright, until recently Editor of Publications; Dr. Frank M. Carpenter, Alexander Agassiz Professor of Zoology and Editor of Psyche. My thanks are also extended to Dr. J. G. Sheals and Mr. D. J. Clark, British Museum (Natural History) and to Dr. W. J. Gertsch, American Museum of Natural History, New York City for the loan of very helpful specimens of the genus Triaeris.

\section{Genus Triaeris Simon, I89I}

The type species is Triaeris stenaspis Simon by monotypy. In addition to the general family characteristics, generic features common to the species from the region under study at this time may be stated as follows: Total length varies from about $1.5 \mathrm{~mm}$ to a little less than $2 \mathrm{~mm}$; Simon gave the length of the type female as considerably more than this. Cephalothorax in general of moderate height; about half as tall as wide; without special modifications. Sternum convex; sometimes more or less distinctly lobed along 
margins; continued laterally between coxae and extended between fourth coxae which are well separated. Chelicerae, maxillae and lip without conspicuous modifications; no teeth observed along fang groove. Eyes: six in two rows with posterior row more or less recurved; figures accompanying descriptions show relative positions of eyes. Male palp simple except for tarsus which appears to have quite distinctive features. Legs moderately long and slender with few spines. Abdomen: ovoid in general; quite tall; dorsal scutum well developed but somewhat variable in size; epigastric scutum surrounds the pedicel and extends dorsally a considerable distance and also varies in size in different species; ventral scutum also quite variable in size in different species; epigynal areas obscurely distinctive. Carapace, sternum and abdomen with numerous short hairs.

\section{Triaeris bodanus sp. nov.}

Figures I-5

Holotype. The male is from Simla, Arima Valley, Trinidad, W. I., April 25, 1964. The name of the species is an arbitrary combination of letters.

Description. Total length about I. $_{\text {I }} \mathrm{mm}$ (abdomen and cephalothorax detached but both parts in good condition). Carapace 0.86 $\mathrm{mm}$ long; about $0.65 \mathrm{~mm}$ wide opposite second coxae where it is widest; about $0.29 \mathrm{~mm}$ tall; gently arched from PME along midline to beginning of moderately steep posterior declivity opposite third coxae; ventral margin smooth. Eyes: six in two rows; posterior row slightly recurved; eyes occupy only slightly more than half the width of carapace at that level (Fig. I) ; irregularities in outlines of eyes appear to be present. Ratio of eyes ALE : PME : PLE $=$ about Io : 7.5:9. ALE separated from one another by about three-fifths of their diameter; barely separated from PLE; separated from PME by three-tenths of their diameter. PME contiguous only at their posterior ends and somewhat divergent anteriorly; narrowly separated from PLE. Height of clypeus slightly more than three-fifths of the diameter of ALE. Chelicerae: of moderate size; vertical; parallel; no teeth observed along fang groove. Maxillae: only slightly convergent; without conspicuous modifications; of moderate length. Lip: somewhat triangular in shape; about two-thirds as long as maxillae. Sternum: convex; distinctly lobed along margins; slightly widest between second coxae; lonaer than wide in ratio of about II: IO: terminated just before 
bases of fourth coxae which are separated by ten-sevenths of their width; third coxae nearly globose; others somewhat elongated with first longest of all. Legs: 4I23 in order of length; with few spines; moderately long and slender; first tibia only a little longer than first patella. Palp: general features shown in Figure 2; tarsus much inflated with cymbium and bulb not clearly separated; femur moderately inflated. Abdomen: general features shown in Figures 3-5; scuta conspicuous and quite distinctive; division between epigastric and ventral scuta obscure; the narrow sclerite often partially surrounding the base of the spinnerets appears to be lacking here. Color in alcohol: carapace and sternum a rich yellowish brown; legs and mouth parts somewhat lighter; abdominal scuta nearly like the carapace and sternum; abdominal areas not covered by scuta are a clear white. Short hairs are numerous over entire surface of abdomen.

Records. One male paratype was taken with the holotype in the vicinity of the William Beebe Tropical Research Station, Simla, Arima Valley, Trinidad, W. I., April 25, 1964.

\section{Triaeris reticulatus sp. nov.}

Figures 6-I3

Holotype. The male is from St. Croix, U. S. Virgin Islands, September 23, 1966. The name of the species is a Latin adjective referring to the faint reticulated color pattern, poorly shown in the holotype but clearer in the female paratype.

Description. Total length $1.56 \mathrm{~mm}$, exclusive of the somewhat extended spinnerets; including spinnerets total length is about I.65 $\mathrm{mm}$. Carapace $0.66 \mathrm{~mm}$ long; $0.54 \mathrm{~mm}$ wide opposite second coxae where it is widest; about $0.27 \mathrm{~mm}$ tall; moderately arched from PME along midline to beginning of moderately steep posterior border gently recurved; surface very finely granulate. Eyes: six in two rows as usual; posterior row recurved (Fig. 6). Ratio of eyes ALE : PME : PLE $=7: 6: 6.5$. ALE separated from one another by about their radius and from PLE only by a line; PME contiguous to one another and separated from PLE by about one half their radius; with considerable black pigment in ocular area. Height of clypeus equal to a little more than the radius of ALE. Chelicerae: vertical; parallel; without special modifications; with numerous slender spinules; no teeth observed along fang groove but close observation impossible without injury to holotype. Lip: very obscure but apparently wider than long and with procurved distal 

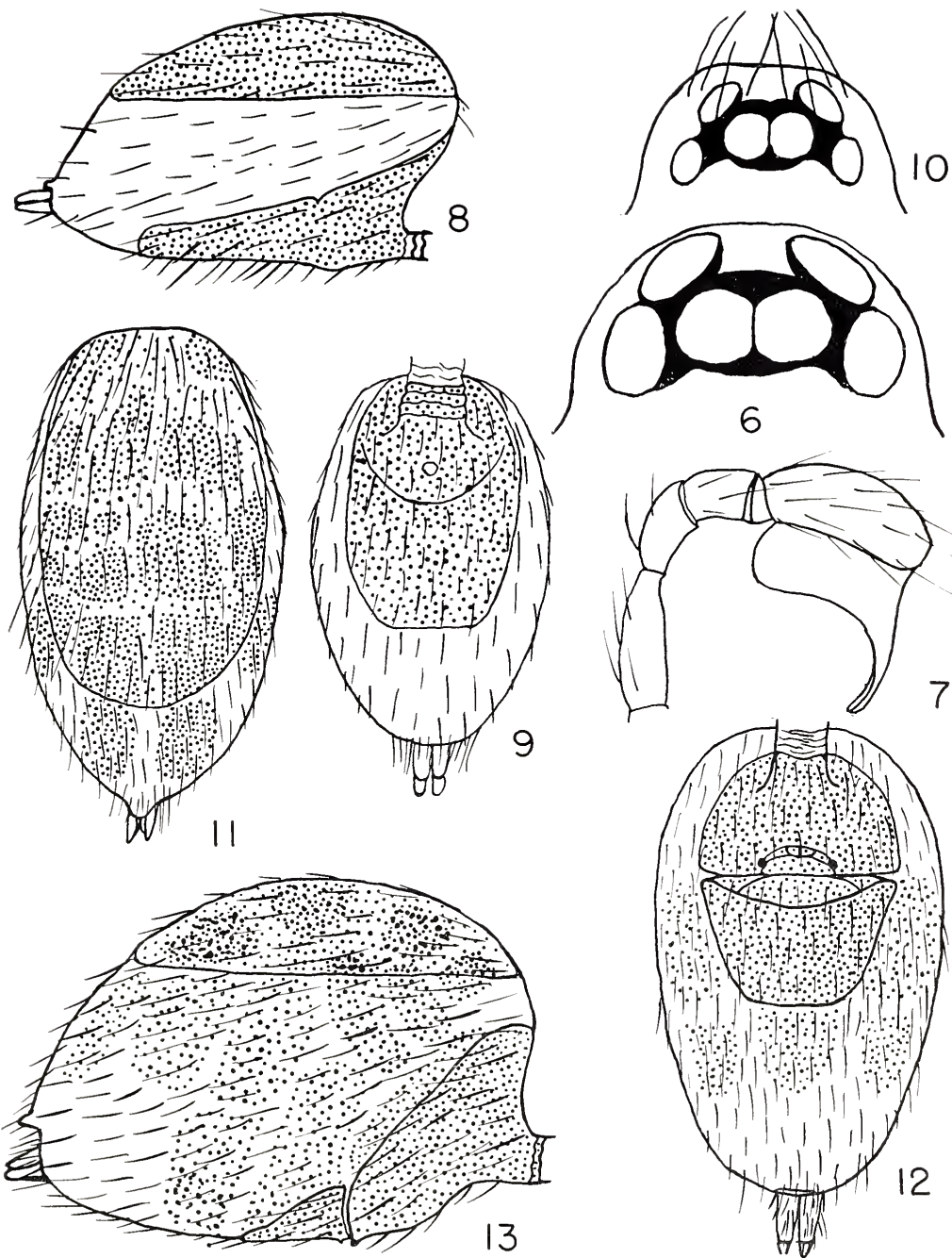

Figures 6-13. Triaeris reticulatus sp. nov. Fig. 6. Eyes of male from above. Fig. 7. Left male palp; prolateral view. Figs. 8-9. Male abdomen; right lateral and ventral views, respectively. Fig. 10. Eyes of female from above. Figs. 11-13. Female abdomen; dorsal, right lateral and ventral, respectively. 
border. Maxillae: normal; without special modifications; moderately convergent. Sternum: convex; recessed along lateral sides of anterior border; broadly scutiform; about as wide as long; bluntly rounded at posterior end which nearly reaches proximal end of fourth coxae which are separated by a little more than their width. Legs: 4I23 in order of length; with few slender spines. Palp: general features shown in Figure 7; all segments except tarsus simple without special modifications. Abdomen: general features shown in Figures 8-9; scuta considerably more extensive than in T. stenaspis Simon. Color in alcohol: carapace and sternum light yellowish brown; with considerable black pigment in ocular area; legs and mouth parts yellowish with variations; dorsal abdominal scutum somewhat darker than the carapace and shows subsurface, irregular reticulations; ventral and epigastric scuta somewhat darker than the sternum; parts of abdomen not covered by scuta are white with very faint purplish reticulations which are much clearer in the female paratype.

Female paratype. Total length, exclusive of the extended spinnerets, about $1.75 \mathrm{~mm}$; including spinnerets, total length is about I.9 $\mathrm{nm}$. Carapace $0.68 \mathrm{~mm}$ long (somewhat overlapped by abdomen) ; about $0.55 \mathrm{~mm}$ wide opposite second coxae where it is widest; about $0.3 \mathrm{I} \mathrm{mm}$ tall; somewhat irregularly arched along midline from PME to beginning of steep posterior declivity nearly opposite second coxae. Eyes: six as usual in two rows; viewed from above, posterior row moderately recurved (Fig. IO). Ratio of eyes ALE : PME : PLE $=$ about $7: 6: 5$. ALE separated from one another by a little less than their long diameter, from PME by about threefourteenths of their long diameter and from PLE by about twosevenths of their long diameter. PME contiguous for nearly onefourth of their circumference and separated from PLE by nearly one-third of their diameter. Height of clypeus equal to nearly fivesevenths of the diameter of ALE. Ocular area with several long, slender spines. Chelicerae moderately robust, vertical and parallel; without conspicuous modifications; no teeth observed along fang groove; lack of paratypes prevents dissection for more accurate observation. Maxillae: convergent; swollen in distal two-thirds. Lip: much wider than long; reaches only a little distal to middle of maxillae. Sternum: quite convex; as wide as long; without noticeable marginal lobes; posterior end bluntly rounded opposite bases of fourth coxae which are separated by about 1.5 times their width; posterior end bordered by a semicircular ridge directed dorsally; with numerous moderately long black hairs. Legs: 4I 23 

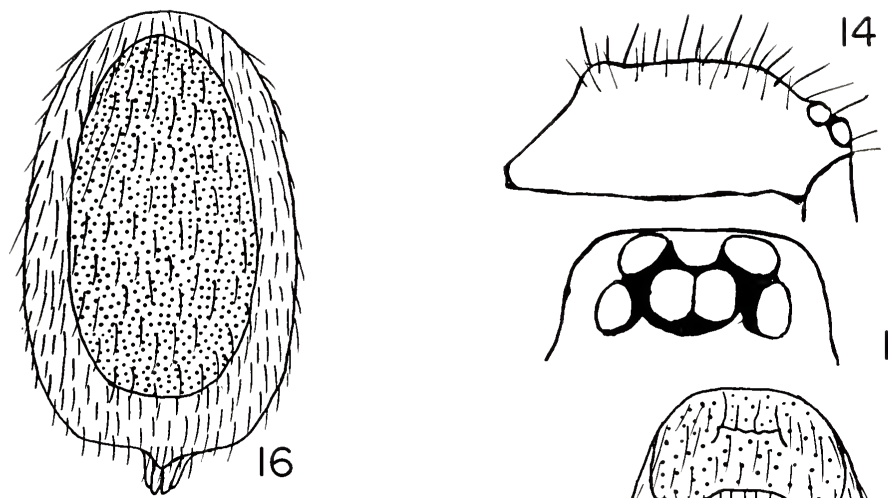

15
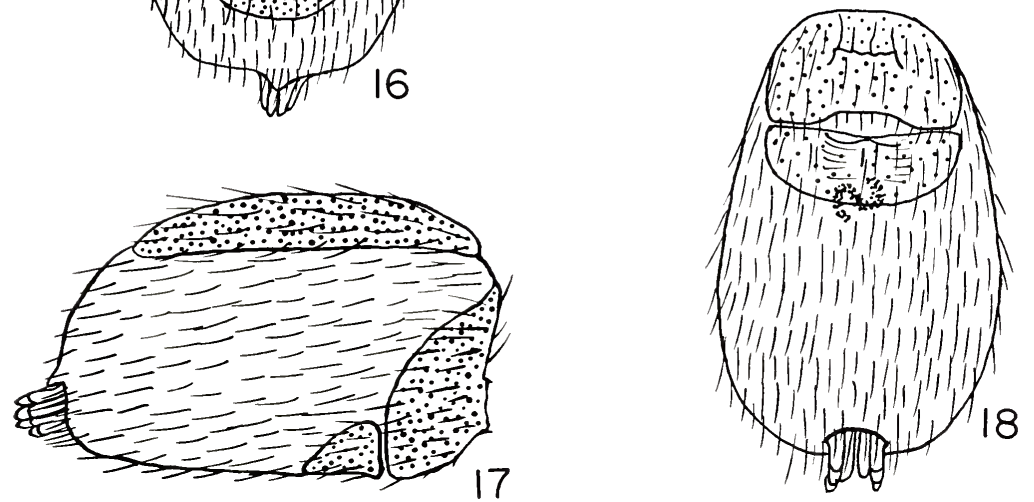

Figures 14-18. Triaeris stenaspis Simon. Fig. 14. Carapace of female; right lateral view. Fig. 15. Eyes from above; from female on loan from the British Muesum (Nat. Hist.). Figs. 16-18. Female abdomen; dorsal, right lateral and ventral views, respectively.

in order of length; first patellae not elongated as in $T$. stenaspis Simon; few true spines on legs and palps. Abdomen: elongate ovoid; with dorsal, epigastric and ventral scuta as shown in Figures I I-I3; with many short hairs; spinnerets somewhat extended. Color in alcohol: carapace and sternum yellowish brown with considerable black pigment in ocular area; legs and mouth parts somewhat lighter with variations; abdomen coarsely and irregularly reticulated more clearly than in male; abdominal scuta basically colored like carapace and sternum but altered by reticulations showing through from within; regions not covered by scuta show purplish reticulations not seen in other specimens in the genus except in males of this species where they show only faintly.

Records. The single individual here regarded as the female of this species was taken on Nevis, B. W. I., September, I 966. 


\section{Triaeris stenaspis Simon}

Figures I4-I 8

Triaeris stenaspis Simon, 1891: 561. The type females from St. Vincent, B. W. I. are in the British Museum (Natural History). Simon, 1892: 443 ; 1893: 302; Petrunkevitch, 1911: 130; 1928: 88; Bryant, 1948: 342.

Triaeris patellaris Bryant, 1940: 268. The type female from Cuba is in the Museum of Comparative Zoology, examined. Chickering, 1951: 243. New synonymy.

A comparison of my specimens, until recently identified as Triaeris patellaris Bryant, with specimens of $T$. stenaspis Simon from St. Vincent, B. W. I. has convinced me that we must now accept the synonymy as given above. Simon gave the length of the type female as $2.5 \mathrm{~mm}$. The specimen from St. Vincent, on loan from the British Museum (Natural History), measured $1.76 \mathrm{~mm}$. Simon published no figures; Miss Bryant published one figure together with an adequate description. With the hope of clarification of the status of this species I have prepared Figures I4-I8.

Collection records. Many localities in Panama, especially in the Canal Zone since 1939. Costa Rica, Turrialba, August 13, 1965. Nicaragua, October, I955 (B. Malkin). Puerto Rico, January, 1964. Tortola, British Virgin Islands, August, i966. St. Thomas, U. S. Virgin Islands, July, I94I (C. T. Parsons). Several localities in Jamaica, W. I., October-November, 1957; February, I955 (P. Bellinger); May, ig56 (C. C. Hoff). Trinidad, W. I., April, 1964. Bermuda, October, I954 (G. Underwood). Bahama Islands, South Bimini, May, i95 I (W. J. Gertsch, M. A. Cazier); July, I95 I (C. and P. Vaurie); March, I953 (A. M. Nadler). Miss Bryant had the species from Cuba and Haiti. A specimen from Miami, Florida, November, ig6r (F. W. Mead) was found in a collection on loan from the University of Florida. Simon reported the species from Venezuela. Obviously, the species is widely distributed. 


\section{BIBLIOGRAPHY}

Bonnet, Pierre

1959. Bibliographia Araneorum. Toulouse. Vol. 2(5).

Bryant, Elizabeth

1940. Cuban Spiders in the Museum of Comparative Zoology. Bull. Mus. Comp. Zool., 86(7) : 249-532, 22 pls.

1948. The Spiders of Hispaniola. Bull. Mus. Comp. Zool., $100(4)$ : $331-447,12$ pls.

Chickering, A. M.

1951. The Oonopidae of Panama. Bull. Mus. Comp. Zool., 106(5): $207-245,31$ figs.

\section{Petrunkevitch, Alexander}

1911. A Synonymic index-catalogue of spiders of North, Central, South America, etc. Bull. Amer. Mus. Nat. Hist., 29: 1-809.

1928. Systema Araneorum. Trans. Conn. Acad. Arts and Sci., 29: $1-270$.

Roewer, C. Fr.

1942. Katalog der Araneae. 1: 1-1040. Bremen.

SIMON, EUGENE

1891. On the spiders of the Island of St. Vincent. Pt. 1. Proc. Zool. Soc. London, Nov. 17, 1891: 549-575.

1892. Voyage de M. E. Simon au Venezuela. Ann. Soc. Entom. France, 61: 423-462, 1 pl.

1892- Histoire naturelle des Araignées. Deuxième edition. Vol. 1. 1895. Librairie Encyclopédique de Roret, Paris.

SUMAN, T. W.

1965. Spiders of the Family Oonopidae in Hawaii. Pacific Insects. $7(2)$ : 225-242, 42 figs. 


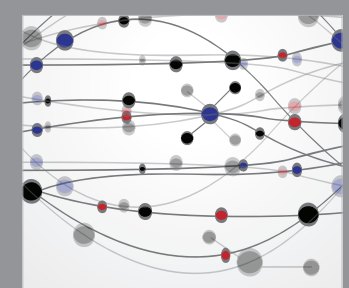

The Scientific World Journal
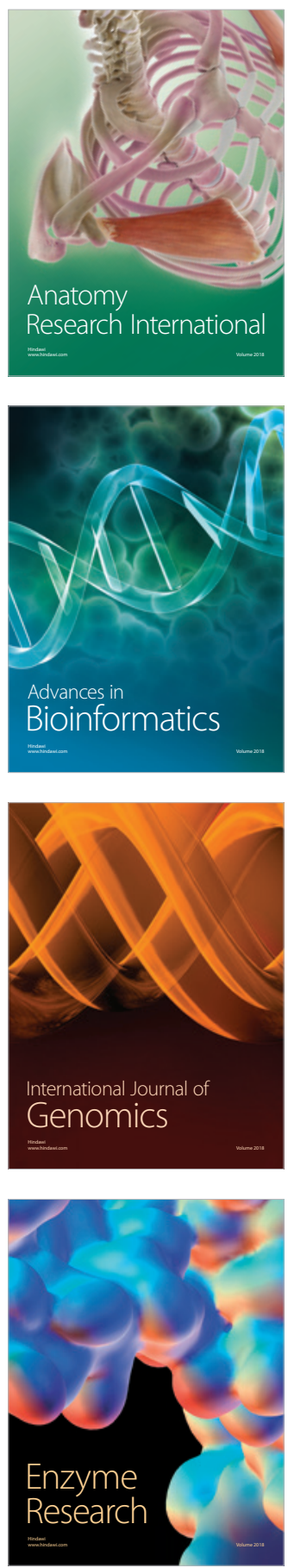
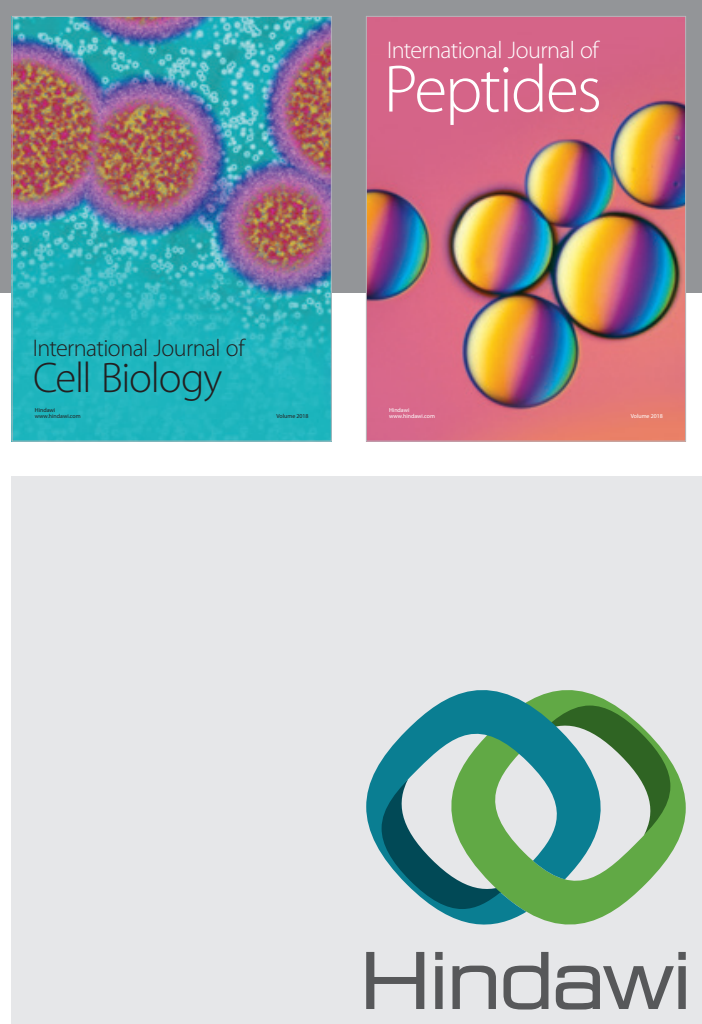

Submit your manuscripts at

www.hindawi.com
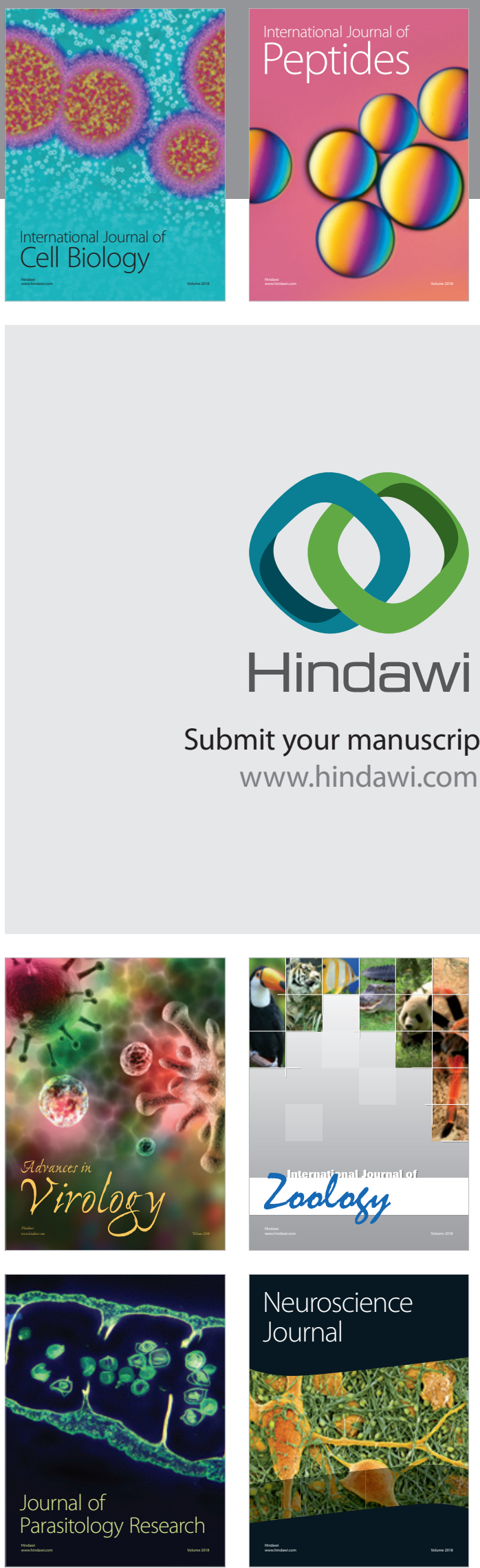
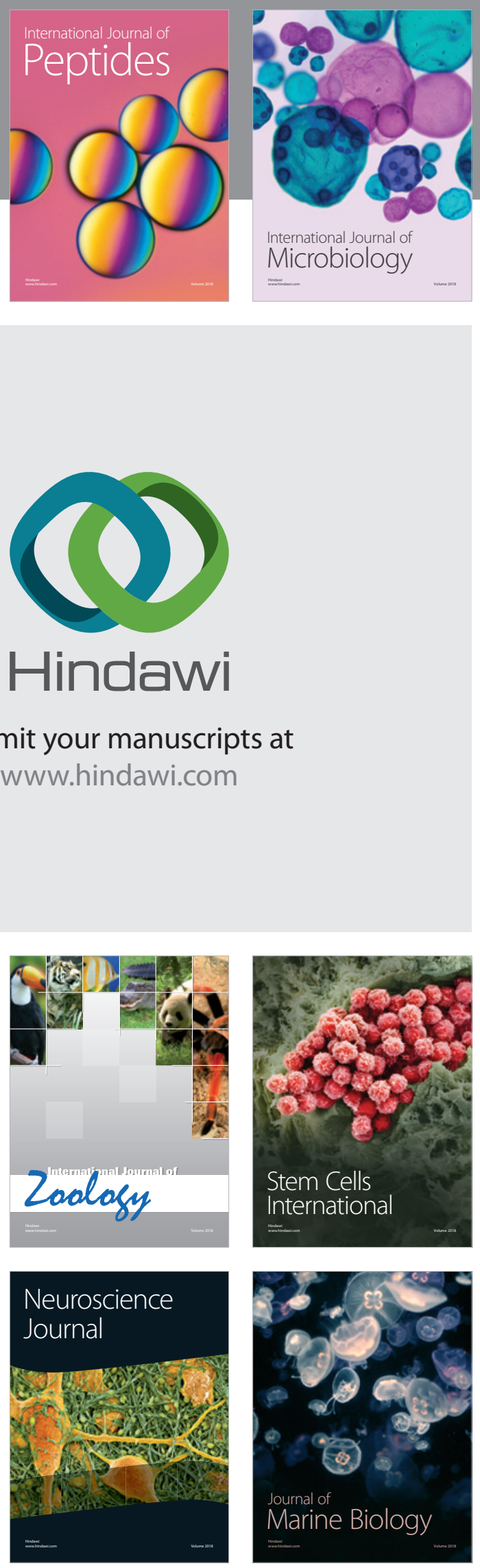
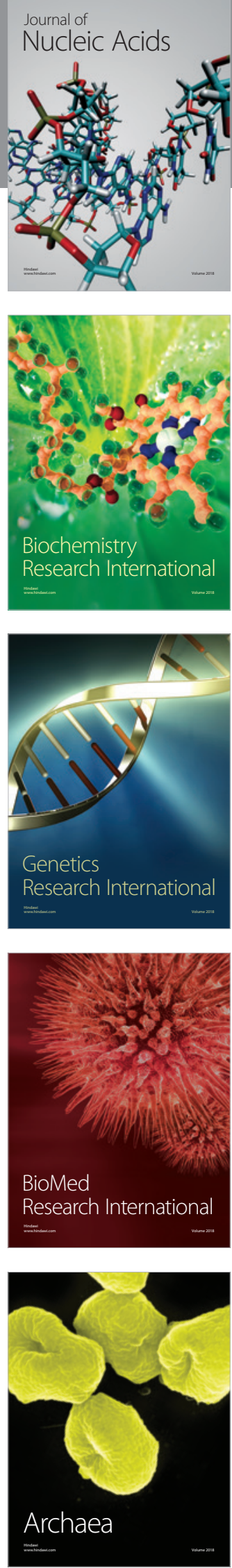